\title{
Model of Implementation of Corporate Social Responsibility (CSR) on Regional Roads in Indonesia
}

\author{
Ayu Surya Arsinta ${ }^{1}$, Mohammad Ichsan ${ }^{2}$ \\ \{ayussurya30@gmail.com¹, mohammad.ichsan@binus.edu ${ }^{2}$ \}
}

Department of Civil Engineering, University of Indonesia, Depok, Indonesia 16424루, Management Department, BINUS Business School Undergraduate Program, Bina Nusantara University, Jakarta, Indonesia $11480^{2}$

\begin{abstract}
It is known that regions in Indonesia are still struggling with funding for the handling of road infrastructure. In this case, the company can carry out its social responsibility to the environment through its Corporate Social Responsibility (CSR) program for road infrastructure. The purpose of this study is to identify the factors that support the creation of the company's CSR on regional roads and subsequently compiled them into a model for implementing CSR factors to improve regional routes in the company's environment. The method used is a literature review method that contains information, theories, and concepts. Data collection through questionnaires and the results of the questionnaires are identified using SEM-PLS and subsequently can be helpful to assist in the implementation of CSR.
\end{abstract}

Keywords: Corporate Social Responsibility, CSR, Road Infrastructure, Implementation Strategy

\section{Introduction}

One of the problems faced by local governments related to road infrastructure today is funding for road infrastructure development. According to Machmud [1], the pattern of regional development financing still relies on budgets sourced from conventional funds such as taxes and levies. The government still relies on increasing local revenue (PAD) in overcoming the limited development funds. This shows that the provincial government has not been able to finance it. CSR can be used as alternative funding for road infrastructure in the region to overcome this problem of funding road infrastructure.

Corporate Social Responsibility (CSR), according to ISO 26000 in Purnama's [2] link, is the responsibility of an organization for the impact of its decisions and activities on society and the environment, which is manifested in the form of transparent and ethical behavior that is consistent with sustainable development and public welfare; taking into account the interests of stakeholders, by applicable law and consistent with international norms; and integrated into all organizational activities, both activities, products, and services. Meanwhile, Suharto states that CSR is a business operation committed to increasing company profits financially and the region's socio-economic development in a holistic, standardized, and sustainable manner.

The author has conducted a preliminary survey to respondents, namely representatives from the Department of Public Works and Public Housing as a local government, regarding which 
areas have received CSR funds for road infrastructure. Respondents who have received CSR are described in the table below.

Table 1. Results of a preliminary survey of road lengths funded by CSR.

\begin{tabular}{lll}
\hline District Code & Island Name & $\begin{array}{l}\text { Length of Road } \\
\text { Funded by CSR }(\mathrm{km})\end{array}$ \\
\hline District A & Sumatera & 18 \\
District B & Sumatera & 12 \\
District C & Sumatera & 1 \\
District D & Jawa & 1 \\
District E & Jawa & 7,7 \\
District F & Jawa & 3 \\
District G & Jawa & 4,6 \\
District H & Kalimantan & 39 \\
District I & Sulawesi & 4 \\
District J & Kalimantan & 300 \\
\hline
\end{tabular}

Based on the above background, the authors would like to research the strategy for implementing CSR factors on regional roads in Indonesia by taking case examples from 10 regions that have managed CSR programs for road infrastructure.

\section{Research Methods}

\subsection{Research Process}

The first research process is a literature study. The variables obtained by the researchers from the results of the literature study were submitted to experts/experts for verification, clarification, and validation. Experts are asked to write comments, responses, and input and add or subtract the proposed variables. The results of the initial expert validation carried out data analysis phase 1 using descriptive analysis. The next stage is data collection. Data collection is done by distributing questionnaires to correspondents regarding the factors in creating road management programs and CSR for regional roads that have been verified, clarified, and validated by experts. This questionnaire will be analyzed using SEM PLS and then produce a model of CSR implementation of companies in Indonesia and the dominant factors of CSR implementation.

\subsection{Modelling}

The flow of the research process is described in the figure below.

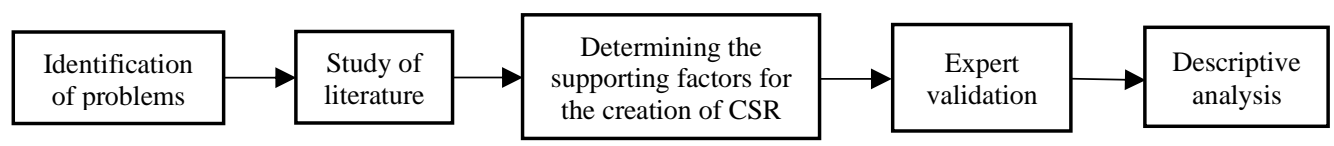

Fig. 1. Phase 1 analysis research process flow. 


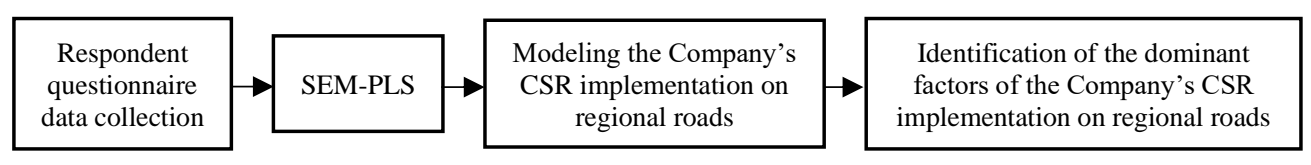

Fig. 2. Phase 2 analysis research process flow.

\section{Results and Discussion}

\subsection{Factors supporting the company's road handling program and Corporate Social Responsibility (CSR)}

Based on the results of expert validation on the factors of creating road infrastructure handling programs and the implementation of CSR, the following results were obtained:

Table 2. Results of road management program factors.

\begin{tabular}{|c|c|c|}
\hline $\begin{array}{l}\text { Road Management } \\
\text { Program Factors }\end{array}$ & Characteristics & References \\
\hline \multirow[t]{4}{*}{ Road conditions } & There is a cracked road & $\begin{array}{l}\text { Wiyono, Widodo, \& } \\
\text { Maryuni } 3 \text { ] }\end{array}$ \\
\hline & There is a grooved road. & $\begin{array}{l}\text { Wiyono, Widodo, \& } \\
\text { Maryuni [3] }\end{array}$ \\
\hline & There is a collapse & $\begin{array}{l}\text { Wiyono, Widodo, \& } \\
\text { Maryuni [3] }\end{array}$ \\
\hline & There is a pothole & $\begin{array}{l}\text { Wiyono, Widodo, \& } \\
\text { Maryuni [3] }\end{array}$ \\
\hline \multirow[t]{3}{*}{ Traffic Volume } & $\begin{array}{l}\text { Light vehicles (sedans, jeeps, } \\
\text { minibusses, pickups) }\end{array}$ & $\begin{array}{l}\text { Wiyono, Widodo, \& } \\
\text { Maryuni [3] }\end{array}$ \\
\hline & Heavy vehicles (buses, trucks) & $\begin{array}{l}\text { Wiyono, Widodo, \& } \\
\text { Maryuni [3] }\end{array}$ \\
\hline & $\begin{array}{l}\text { Two-wheeled motor vehicle } \\
\text { (motorcycle) }\end{array}$ & $\begin{array}{l}\text { Wiyono, Widodo, \& } \\
\text { Maryuni [3] }\end{array}$ \\
\hline \multirow[t]{2}{*}{ Policy } & Musrembang Kecamatan & Trissiyana $[4]$ \\
\hline & Musrembang Kabupaten & Trissiyana [4] \\
\hline \multirow[t]{4}{*}{ Land Use } & $\begin{array}{l}\text { Support for agriculture and } \\
\text { plantations }\end{array}$ & $\begin{array}{l}\text { Wiyono, Widodo, \& } \\
\text { Maryuni [3] }\end{array}$ \\
\hline & Education support & $\begin{array}{l}\text { Wiyono, Widodo, \& } \\
\text { Maryuni [3] }\end{array}$ \\
\hline & Support for trade and services & $\begin{array}{l}\text { Wiyono, Widodo, \& } \\
\text { Maryuni [3] }\end{array}$ \\
\hline & Social and cultural support & $\begin{array}{l}\text { Wiyono, Widodo, \& } \\
\text { Maryuni [3] }\end{array}$ \\
\hline Fund & Budget allocation & $\begin{array}{l}\text { Fatan, Purnawan, } \\
\text { Putri [5] }\end{array}$ \\
\hline Human & $\begin{array}{l}\text { Excessive and repetitive vehicle } \\
\text { loads }\end{array}$ & $\begin{array}{l}\text { Munggarani, N. A \& } \\
\text { Wibobo, A [6] }\end{array}$ \\
\hline & $\begin{array}{l}\text { Non-adhesive spills such as oil, } \\
\text { wastewater, water, etc. on the } \\
\text { pavement surface }\end{array}$ & $\begin{array}{l}\text { Munggarani, N. A \& } \\
\text { Wibobo, A [6] }\end{array}$ \\
\hline
\end{tabular}


Table 3. Results of CSR factors.

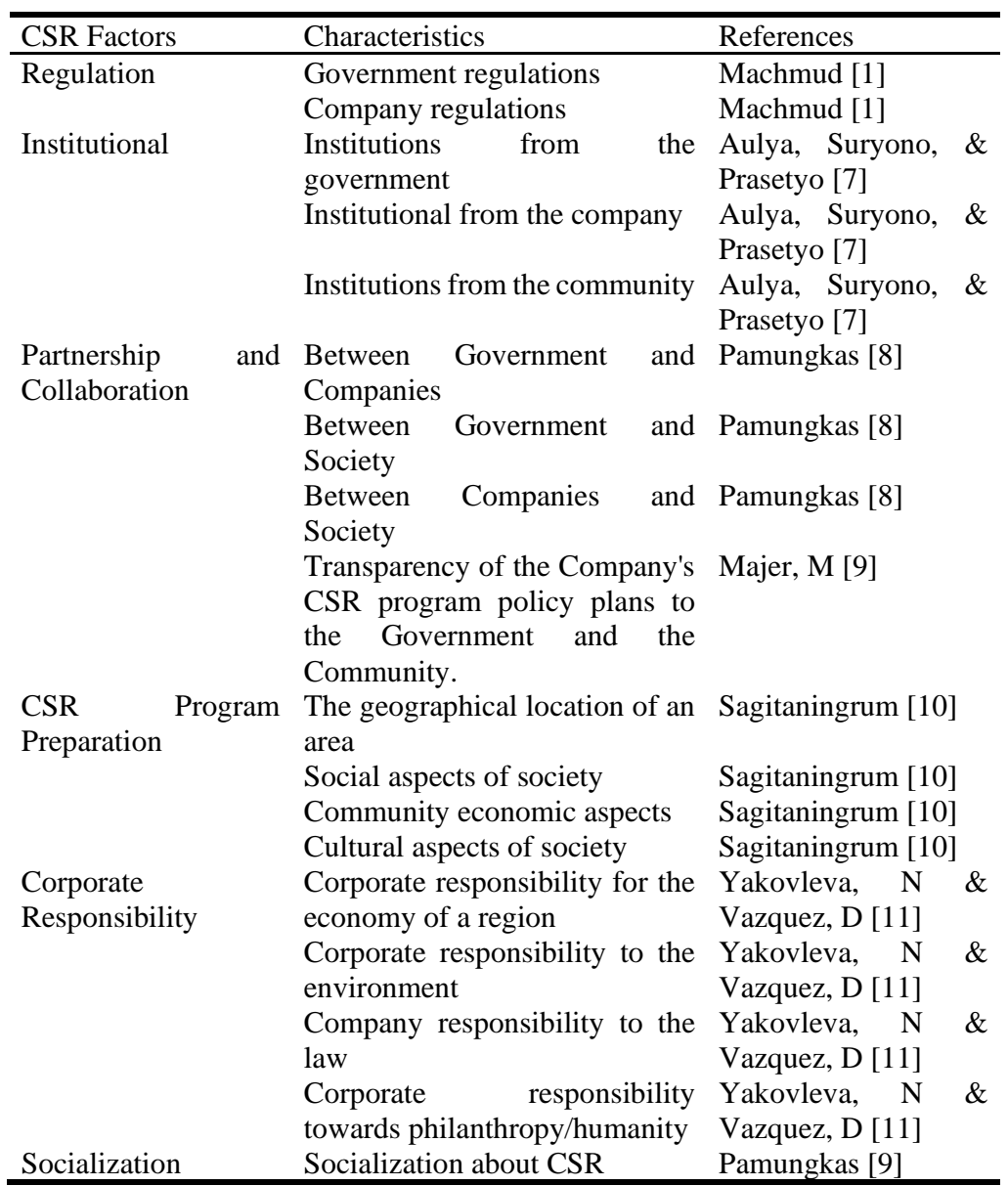

\subsection{Modeling between road management programs and the Company's CSR towards improving local road handling}

The questionnaire results were processed using the SmartPLS application, and the results formed a model of the existing factors. Following are the results of this research modeling using SmartPLS. 


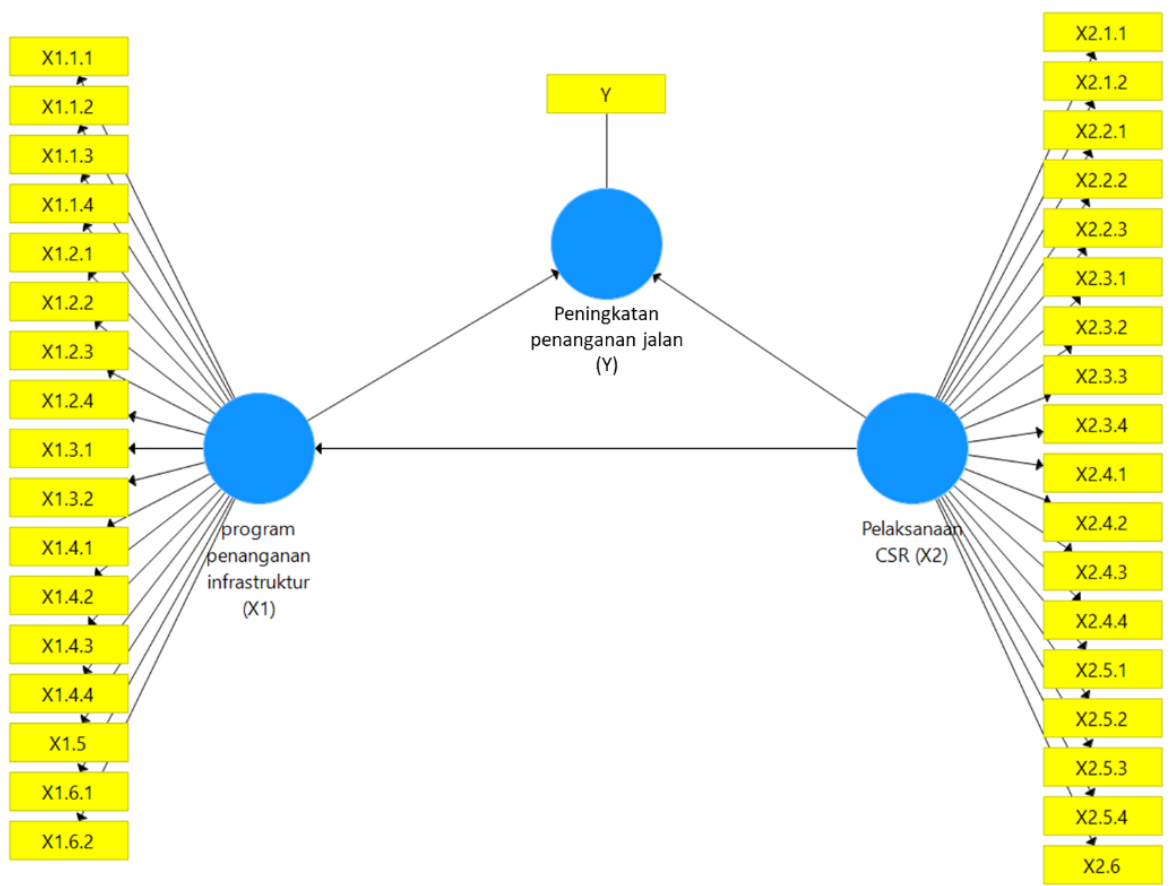

Fig. 3. Modeling between road management programs and the Company's CSR towards improving local road handling.

\subsection{The dominant factor of the company's CSR implementation on improving road handling}

From the T-test using the SmartPLS application, it can be concluded that the order of factors that influence the implementation of CSR from the most influential is as follows.

1. Institutions from the community

2. Partnership and collaboration between the company and the community

3. Teamwork and cooperation between Government and Companies

4. Company regulations

5. Institutional from the company

\section{Conclusion}

The T-test and the direct effect test on the SmartPLS application show that the road infrastructure handling program variable significantly affects the road holding improvement variable. Furthermore, the CSR implementation variable has a significant influence on the road infrastructure taking program variable. Meanwhile, the CSR implementation variable has an insignificant effect on the road handling improvement variable.

So this research shows that the implementation of CSR does not need to be made a special regulation by the government. But suppose the government wants to implement CSR to improve road handling. In that case, the government can apply the dominant factors for the creation of 
CSR in this research, including create institutions of the community, build partnerships and collaborations between companies and communities, build partnerships and cooperation between the government and companies, make local government regulations and organize the institutions of the company. Suggestions for further research is that the company can be used as a point of view in future research.

\section{References}

[1] Machmud S. Kajian Pemanfaatan Dana Corporate Social Responsibility Sebagai Alternatif Sumber Pembiayaan Pembangunan Daerah. Jurnal Ekonomi, Bisnis \& Enterpreneurship. 2015; Vol. 9 (No. 1): 29-44

[2] Purnama, K A. ISO 26000 Sebagai Pedoman Baru Tanggung Jawab Sosial Perusahaan (CSR). Lumbung Nuswantara; 2012

[3] Wiyono, W., Widodo, S., \& Maryuni, S. Analisa Penentuan Urutan Prioritas Pemeliharaan Jalan di Kabupaten Landak Provinsi Kalimantan Barat dengan Menggunakan Proses Hirarki Analitik. Jurnal Mahasiswa Teknik Sippil Universitas Tanjungpura. 2016

[4] Trissiyana. Penentuan Prioritas Pemeliharaan Jalan Kabupaten. Jurnal Ilmiah Teknik Lingkungan. 2017; Vol. 2 (No. 2): 13-19

[5] Fatan, R., Purnawan, \& Putri, E., E. Analisa Kondisi Kemantapan Jalan Nasional Provinsi Riau Terhadap Volume Lalu Lintas dan Alokasi Anggaran. Jurnal Rab Construction Research. 2017; Vol. 2 (No. 1)

[6] Munggarani, Wibowo. Kajian Faktor-Faktor Penyebab Kerusakan Dini Perkerasan Jalan Lentur dan Pengaruhnya Terhadap Biaya Penanganan. Jurnal Infrastruktur. 2017; Vol.32 (No. 1)

[7] Aulya, R., Suryono, A., \& Prasetyo, W. Y. Implementasi Program Corporate Social Responsibility Dalam Rangka Mewujudkan Sustainable Development di Building Lingkungan. Jurnal Administrasi Publik (JAP). 2014; Vol. 2 (No. 4): 608-612

[8] Pamungkas, B. Kerangka Pengaturan Pengelolaan CSR Terpadu (Studi Kasus di Kota Jakarta). Jurnal Ilmu Hukum. 2017; Vol. 2 (No. 1): 65-80

[9] Majer, M. The Practice of Mining Companies in Building Relationships with Local Communities in The Context of CSR Formula. Journal of Sustainable Mining. 2013; Vol. 12 (No. 3): 38-47

[10] Sagitaningrum, D. Keterkaitan Letak Geografis terhadap Desain Program dan Pelaporan CSR Perusahaan. Jurnal Ekonomi dan Bisnis. 2015; Vol. 18 (No. 3)

[11] Yakolava \& Vazquez. Stakeholder Perspectives on CSR of Mining MNCs in Argentina. Springer Science + Business Media. 2012 